\title{
Beyond Identity Problem: Perspective of a Chinese Teacher of English
}

\author{
Wensheng Deng \\ Department of Foreign Languages, Beijing Institute of Petrol-chemical Technology, Beijing, China
}

\begin{abstract}
With intensive globalization, Chinese teachers of English have more and more involved into cross-cultural communication. Throughout the communication, cultural conflicts have also arisen. Thus, Chinese English teachers have to face the conflicts in their teaching practice. For their specific and unique role, they are in the dilemma to either preserve his identity of Chinese culture or lose it to get a new identity of English culture. That is why the thesis has started to explore. The thesis digs out the reasons which have led to the conflicts of cultural identity---ideologies, the roots of the conflicts. As to the crisis of identity, the thesis offers the following solutions to Chinese English teachers. First, he should have a kind of consciousness or experience of Chinese culture and Western culture; second, he should get something critical in absorbing other cultures; third, he should remember that it is his goal to cultivate young generation with proper identity of moral attitudes, beliefs, personalities and values.
\end{abstract}

Index Terms—identity, cultural conflict, ideology, English teaching

\section{INTRODUCTION}

For Chinese teachers of English, identity problem is something unique and specific. They are distinctive and different from other counterparts over the world because of social institutions, cultures and history. With intensive globalization, a power to push forward cross-cultural communication, the interaction of national cultures over the world is speeding up as well. Simultaneously, China's opening-up to the world has brought about more opportunities to contact with other cultures for average citizens, especially for teachers of English, because English is the most widespread language among nations of the world, they have no language barrier. One more special reason is that One Belt and One Road Initiative being implemented is pushing forward the tendency of the cross-cultural communication. Under such a circumstance, every nation has accelerated the pace of modernization. Hence, the national identity, influenced more or less by the communication, embarking on culture diversities, starts to change. So it does for us Chinese teachers of English. And the status qua of their identity is changeable, and highlighted from both ethical and political viewpoint. But the reason to make the change is not clear. To clarify it, this thesis is going to discuss the problem of cultural identity of Chinese English teachers; and it is our hope that we would find some solution to it.

\section{Literature ReVIEW OF IDENTITY PROBLeM}

\section{A. Identity Studies in West}

Dating back to the history of identity studies, we can find there is a development clue in Western academy. The early studies of identity started from John Locke (1632-1704), a British philosopher. His ideas about identity almost are sources of the latter theory related with it. He claims that personal identity is conscious, spiritual, not survival. He made clear and careful studies on aspects of individual identity. (Harold W. Noonan, 2003, p24-43)Locke's theory is spread in various disciplines, from philosophy, psychology, politics and cultural studies, sociology, to anthropology, etc. Among the disciplines, psychology, politics and cultural studies are relatively remarkable. Sigmund Freud (18561939), an Austrian psychoanalyst, is one of the earliest explorers to the study. He thinks that individual identity is connected with his community or his relationship with others. Jacques Lacan (1901-1981), French psychoanalyst, on one hand, who admits Freud's unconscious theory, claims that language is also controlled by individual unconsciousness. On the other hand, he believes that individual subject or identity is affected by self-mirror image, is a self-cognition after one had contacts with his mirror image and language. The subject of identity is distanced from or alienated by the language, so "language learning is the beginning of violence, conceal, repression or estrangement." (Qi Xiaobin, 1994, p.72-77)

From 1950s to 1960s, a bunch of scholars contributed a lot to the studies of identity. Erik Erikson, an influential and pioneering psychologist in US, has proposed an enduring theory of development. He believed that the conflict, occurring during one's adolescence, is "identity versus role confusion." Erikson claims that identity encompasses the memories, experiences, relationships, personalities and values that create one's sense of self. This amalgamation creates a steady sense of who one is over time, even as new facets are developed and incorporated into one's identity. ${ }^{1}$ His

1. http://en.wikipedia.org/, 10/21/2019. 
theory has indicated that identity is complicated, constructed and mobile, which has impacts upon latter researchers. Obviously, Erickson has combined psychology with ethics in the studies, which is a great progress on the identity studies.

Western scholars have focused on politics and ethics from last 1970s 1980s, because there are problems resulted from multiple races and cultures at home and abroad. (Zheng Wei \& Zhang Liang, 2018, p.65-78) There are researchers who have formulated identity theories in politics and cultural studies. For instance, Barth put forward a theory of identity - theory of cultural identity, which refers to individuals could locate himself according to personality frame of reference from culture and tradition. Hamers and Blanc stress that cultural identity is a result of individual socialization, which has started to form and developed from his childhood, a compound of cultural structure and individual personality. Stuart Hall holds that cultural identity consists of two dimensions. First, cultural identity is a culture shared with a community, a genuine ego with a collective, which is hidden in other individuals, sharing history and ancestor with others; the second one is that cultural identity is an existence and change. It's not only a presence today but also in the past and in the future. It's an existence beyond time, place, history and culture. (Lee Danjie, 2015, p. 27-28)

\section{B. Identity Studies of English Teacher in China}

In China, identity studies are also popular; it is mainly focused on culture. It is not started until the late 1990s in foreign language studies, though few scholars had brief mentions of it. Most scholars from foreign languages just are devoted into the identity of foreign language teachers from perspectives of pedagogy, academics and self-development, whose research have concentrated upon individual state as an English teacher or how to enhance self-academic ability. Not many of them have paid enough attention to conflicts of cultural identification between West and China. Nobody has explored problem of ideological conflicts.

As to the discussion of the identity of English teachers in China, most of scholars, publishing their theses related with it through journals or papers, have mainly focused on two aspects: one is based on academic development at different stages, for example, the shift from teaching English majors to non-English majors, which have new standards and requirements for English teachers; the other one is from the shift of English teaching renovation, which have resulted in corresponding shift of the identity of English teacher, i.e. from traditional role, to a modernist, like co-operator, partner and guider, and so forth. The domestic scholars have presented solutions to the identity problems as an English teacher. That is, self-constructing personal studies and self-enhancing academic abilities of one's own. The second way for us teachers is that they have to throw off old notions and ideas as a teacher: such as teacher-oriented idea; a teacher is not an authority, a dominator, a leader of leaners anymore; now, the new approach advocates a style of student-oriented teaching method in class. The means and methods, adopted by researchers in domestic literatures, are qualitative approach and few are quantitative one. Such discussions could be dated back to last 20 years, though some scholars have mixed both methods. The former method is represented by Professor Xiang-ming Chen; the latter one is highlighted by Professor Yi-hong Gao. Chen has put forward a set of theory system, a teacher's practical knowledge, who has regarded them as the teacher's identity. It is a breakthrough of the identity theory by domestic scholars. Professor Gao has done a series of field research. Her studies are influential on English colleagues in China though she mainly uses a quantitative way.

Hence, from the analysis given above, at least, we can see that there leaves some gap in the studies of identity of language teachers, especially English teachers, from political and ethical perspective, which indicates a problem of language teaching in China. Having been under the influence of the structuralism linguistics for a long time, most university courses of language teaching, taking English as an example, regards language as only a tool instead of a cultural construction. In doing so, the language teachers can only have the form of language taught, like English performance, but not the essential content of culture - the culture hidden behind the language. No wonder, it is harder for an English major graduate to hunt for a job. The situation is hard to change if he can only possess the ability of basic skills, like listening comprehension, speaking, reading, writing and translating. If we traced back to roots of the problem, without any exaggeration, the teachers should have be partially responsible for the situation. On the contrary, if a teacher of English is aware of his identity, not only a role as a language teacher, in the course of teaching English, not only giving language points, but also critically introducing culture to learners as well, to both the teacher and the learner, it is of vital importance to form proper values on world, life and the like. The problem of today could be dissolved only if the roots of identity crisis had been eradicated. But, to our regret, most of the teachers are not always conscious of the problem at all.

\section{IDENTITY PROBLEM OF ENGLISH TEACHER IN CHINA}

\section{A. The Instability and Polysemy of Identity}

For human beings, identity is always mobile, never stable. From the time immemorial, which ancestors of human beings were migratory, not residents of a place for a long time but movable here and there because of climate, disease or war, etc., the identity problem has arisen. When they stay in hometown, their identity is native; however, while they have newly travelled to another place, the identity is a sojourner but not a local anymore. The identity, therefore, is constantly changed as the ancestors have been moving around from place to place. To a certain extent, actually, human 
history is a history of migration. As it is known that our ancestors are wanderers in Eastern Africa from the earliest time on, then, they are travelers here and there over the world in the present. They have no permanent identity at all until they are settled down in a region. Yet, until today, the identity for us is still problematic without fixed content, and it is present anywhere even after millions of years were elapsed.

The long history of identity problem has brought many meanings to the word to locate the uncertainty of identity itself. If we look it up in a dictionary, we can find that it is problematic for us to use with many meanings. Etymologically, it was first used in 1545, in Middle French as identité, from Late Latin identitat-, identitas, probably from Latin identidem repeatedly, contraction of idem et idem, literally, same and same. ${ }^{2}$ After several centuries, it has derived into four main senses, a polysemy. According to Random House Webster's Dictionary of American English, there are four entries of meanings listed as the following:

a. the state or fact of remaining the same; the condition of being oneself or itself and not another;

b. condition or character as to who a person is or what a thing is;

c. the sense of self, providing a feeling of sameness and continuity; individuality;

d. the state or fact of being the same one as described. ${ }^{3}$

For its polysemy, the user often feels puzzled; he doesn't know which is which to describe his state. So, semantically speaking, identity itself has brought forth some confusion.

\section{B. Identity Problem of Chinese English Teacher}

For Chinese teacher of English, in the context of globalization, the biggest problem that he has being faced is crisis of cultural identity. He is just at the center of the conflicts between English culture and Chinese one. As we know that language is a carrier or medium of culture. So, the two languages represent different cultures, which can be embodiment of ideologies respectively. Except some of universal ideas shared by the two cultures, they're different from each other and probably have conflicts on political systems, worldviews, values and governing. Anything harmful, corruptive or conflicting against our morality, faith, public institution or patriotism is not suitable for us to cultivate young generation. For example, American scholar of politics, Francis Fukuyama, describes the so-called life of "megalothymia" like this:

"These wealthy, secure societies are the domain of Nietzsche's Last Man, "men without chests" who spend their lives in the endless pursuit of consumer satisfaction, but who have nothing at their core, no higher goals or ideals for which they are willing to strive and sacrifice. Such a life will not satisfy everyone. Megalothymia thrives on exceptionality: taking big risks, engaging in monumental struggles, seeking large effects, because all of these lead to recognition of oneself as superior to others." (Francis Fukuyama, 2018, p.9)

Obviously, such kind of life or society is mentally corruptive to young Chinese's mind and mentality. It shows that the conflicts of ideology are present throughout the two cultures. For the dilemma, it is embarrassed for a Chinese teacher to keep a balance between the two. As a role of English teacher, he has to keep the state or condition, i.e., his identification with English culture, recognizing it, so he could understand it better to explain the culture in and out, which is a standard to be a good teacher. But, on the other hand, being a Chinese, he is supposed to preserve Chinese 'cultural memory' (Jan Assmann, 1938--), not only should he trust Chinese culture but also love it. But, for him, as an English teacher, he has learned English for years; English culture has become a part of his set of knowledge. Even some of the culture, i.e. religion, tradition, custom, democracy, life style, in short, Western ideologies, which have been integrated with his daily life and social experience, are accepted whole-heartedly by him. Thus, it is natural for him to act in an English manner in daily life. Regrettably, they even don't realize they have been playing the role of spokesman for English culture. The status quo has led them to a kind of embarrassment. How could they both recognize English and resist Chinese or vice versa? The trouble is just like what Holy Bible says, "No one can serve two masters. Either he will hate the one and love the other, or he will be devoted to the one and despise the other. You cannot serve both God and Money." (Matthew, 6:24) The scriptures quoted here means: an English teacher is devoted to English culture or Westernized one; it is probably true to say that he can't just love it anymore, so it is impossible for him to comment it from an ethical way, let alone criticize it or find faults in it. In a word, he just trusts the language and culture. He has internalized them into his personality. Probably, that is why they aren't willing to analyze the danger hidden behind English culture and teaching; it's difficult for them to guard against harms from Western ideologies, which is conveyed in English cultures with the medium of English language. Again, it is as the scripture reads, "The man who thinks he knows something does not yet know as he ought to know." (1 Corinthians, 8:2) English teachers trust the faith or ideas in English too much and don't know they are trapped into it. Though they know the saying "Every coin has bright side and dark side", they forget it completely in teaching. It needs some time for them to change their deep-rooted faiths of the culture, and get rid of the conflicts.

A second problem for English teacher of China is that they have hardly realized what is hidden behind English teaching. That is, they don't understand what on earth is the problem disguised under the teaching job. Apparently, the job is one of the safest professions because it has no fatal accident around him. In a lesson, there are various activities organized to present language points; students are attracted by them. In fact, they are falling into a trap like a blind riding a horse so it is hard for them to cast off poisonous effect from English culture, because most of us have taken it

2.https://www. merriam-webster.com/dictionary/identity, 10/21/2019.

3. Gerard M. Dalgish (ed.), Random House Webster's Dictionary of American English, New York: Random House, 1997. 
for granted that language is neutral and innocent. In fact, politically, English language is one of culture hegemony'(Antonio Gramsci,189-1937) and'political power'(Michael Foucault,1926-1984). Therefore,"language learning is the beginning of violence, conceal, repression or estrangement." (Qi Xiaobin, 1994, p.72-77) As is known to the world, English is not widespread over the world until British Empire began its overseas colonial expansion and global trade after Industrial Revolutions. With British colonization, English goes to global step by step, and has been accepted as an official language or second official one by more than 110 countries in the world. Gunfire, vessels and opium are pioneers for English to be prevailed. Admittedly, to some degree, English has brought about a kind of modern civilization to the colonized nations; however, there are few of us who are aware of culture loss---the death of native languages. A great number of ethnic languages are died out of the Earth forever. The ecosystem and balance of language are disrupted or destroyed, and the diversity of languages is being disappeared. The vanished Indian dialects are just proof to the loss. A lot of Indian speeches and dialects have been dying out since Mayflower was docked in Nov. of 1620 at Plymouth in the brave new world; so does the languages in Africa, Asia and Australia. Wherever English is spoken, English culture and civilization are brought there. The enslaved nations are forced to use the bragged new paradigm or standard in English. Nowadays, the place of English as a hegemony and 'ethnocentricity' (William Graham Sumner, 1840-1910) is established and strengthened increasingly because of American power, which is waging a culture war against its opponents to spread its ideologies, with the disguises of cultural products, such as Hollywood movies, Apple products, and McDonald snacks, etc. throughout the world. The products are thoughtless, nevertheless, what is hidden behind them implies that English ideology is central, other is marginal; a new inequality of culture comes into being. Though, apparently, we are teaching only English, we might be quiet accomplices of English imperialists, and constant contributors to the inequality, hegemony and ethnocentricity. Therefore, undoubtedly, there are enormous hazards and risks hidden behind English teaching. It's never careful enough for us to be alert to them.

\section{CAUSE OF THE IDENTITY CRISIS}

The root of the identity crisis lies at the conflicts of the ideologies represented by the two cultures, which are embodied by the two languages. Hence, we are both teachers of English and watchdogs of ideology as well. In fact, if we go back to history of intellectuals in West, we will find that censorship has a long history. In Plato's Republic, Plato stresses that a poet can't be a ruler of a nation, because he would nourish young men with improper ideas and is expelled out of it. It shows that ideological conflict in education is realized clearly from old Greek.

Ideology, the term, was coined by French philosopher Destutt de Tracy (1754-1836) to describe the science of ideas: that is, the discipline that would enable people to recognize their prejudices and biases. Afterwards, Karl Marx (1818-83) and Friederich Engels (1820-95) developed the concept, which designates culturally determined bodies of ideas meant to advance the interests of certain social groups; often to the detriment of others.(Dani Cavallaro, 2007, p.75) A lot of philosophers in West have proposed various definitions of ideology. The main ones are listed here as follows:

- a body of ideas, ideals, values or beliefs;

- a philosophy;

- a religion;

- false values used to keep people under control;

- a set of habits or rituals;

- the medium through which a culture shapes its world;

- ideas promoted by a specific social class, gender or racial group;

- the values that sustain dominant structures of power;

- the process whereby a culture produces meanings and roles for its subjects;

- the alliance of culture and language;

- the presentation of cultural constructs as natural facts.(ibid)

Thus, from the definitions listed above, we can see that ideology is mainly a set of ideas, not necessarily referred to something political, or economic. In a nation with multiple ethnics, the ideology of dominator is legitimated consequently by using all sorts of strategies. So, it is endowed with the role of master ideology among others. A nation always tries its efforts to spread and promote its ideology to other nations by all possible means and methods. Only the ideas, which are contradictory or conflicting among nations, are excluded by opponents. From Socrates (470B.C.-399B.C.) \& Plato (427B.C.-347B.C.) in ancient Greek until Samuel Phillips Huntington(1927-2008), Daniel Bell (1919-2011) \& Francis Fukuyama (1952-) in modern America, ideological conflicts are highlighted all the time. The capitalist nations have been waging a war of ideologies against socialist ones since the day socialism was established, and Cold War is one of the proofs of ideological conflicts.

In teaching practice, ideological conflicts are often concealed in the text for learners. We should analyze it carefully to expose them, like text attitude, implied moral tendency, ethnocentricity, etc. For example, there is a text entitled "The Pursuit of Dreams", which is a story of how a deaf guy has come into his dream to be a DJ. ${ }^{4}$ The textual attitude is very encouraging, inspirational to the students. However, if we go into the reason that has led the hero to a deaf, we can find

4. The text"The Pursuit of Dreams" referred here is adopted from New Progressive College English Integrated Course Book 1(Ji Pei-ying \& Feng Yu, eds.), Shanghai: Shanghai Foreign Language Education Press, 2017, p.12-16. 
it was just the high price of treating ear that his family could not afford, because they had no health insurance at that time. From the reason and the text, we can discern the implied ideologies as the subsequent:

a. the country referred in the text is a paradise for the rich;

b. the country has a good system of health insurance;

c. a doctor in the country is likely to be highly paid;

d. individualism culture is encouraged in the country;

e. prestigious economy and consumer economy is popular;

Therefore, a teacher should make ethical decisions about the ideologies conveyed between lines in the text. He is supposed to tell his students which is good, like b, and which is bad, like a or e, and which is universally accepted over the world, like $\mathrm{c}$ and $\mathrm{d}$. We may also ask the students to have a discussion of the ideas and make the choices of their own. As to political ideology, sometimes they are expressed in some English works and are of hostility to Chinese culture, especially untrue to our history and political institution. Like the book Identity: The Demand for Dignity and the Politics of Resentment written by Francis Fukuyama, ${ }^{5}$ it is clear for us to resist the political ideology implied in the book, and we should dig out the historical situation, and make it known to the students.

\section{SOLUTIONS TO IDENTITY CRISIS}

Faced the identity crisis, we are supposed to work it out. Here are some ways to it. In the first place, as a teacher of English in China, he should have a kind of consciousness or experience of Chinese culture, including history, politics and tradition, and the like, to be subject of Chinese culture. As the inscription "Know thyself!" engraved in Parthenon Temple of Greek shows, one must understand himself, then can he know others well. By doing so, he is able to acquire the identification with Chinese culture and be proud of classics of it; he will be confident with it and have trust on it. In the meanwhile, he should also know something about Western culture, including history and politics so that he can absorb advantages and resist disadvantages of other cultures. In doing so, we should distinguish homogeneity and heterogeneity from other culture with Chinese one.

Second, we should get something critical to absorb other cultures, and put it into teaching practice. For instance, when we are taking or introducing other cultures to young people, we are able to be critical to do so, be an examiner or a censor of cultural products. In the analysis of other cultures, we ought to find textual attitude, discourse authority, ethnocentricity, ideological hegemony and imperialism underlying throughout course books; we must be aware of other ideologies, may not lose our moral personality, identity or self in doing so. In the meanwhile, confronted with various forms of contemporary cultures, such as fan culture, consumer culture, body culture, prestigious economy, new geist and the like, certainly, we are open to them, but we should make use of proper parts of them to be infused with ours, it is not intelligent for us to resist them for once and all. So, particularism to other is stupid. Of course, in the communication with other advanced cultures, we shouldn't necessarily feel inferior to others and get a kind of nihilism to self or otherwise, i.e. nationalism, advocating national supremacy. Both of the two extremist attitudes are improper in cross-cultural communication and should be thrown off. The proper way for us to look at new, modern cultures is to have a critical eye and open mind.

Third, we should remember that it is our goal to cultivate young generation with proper identity of moral attitudes, beliefs, personalities and values, who are able to play positive roles in our society and family, to preserve our classical cultural memories, and our hopes for the future. Though most of these things can, of course, change all the time, the young generation can switch jobs, move to a different community, or experience a kind of life changing circumstances that challenge our beliefs.

\section{REFERENCES}

[1] Cavallaro, Dani. (2007). Critical and Cultural Theory: Thematic Variations. New Jersey: The Athlone Press, p.75.

[2] Fukuyama, Francis. (2018). Identity: The Demand for Dignity and the Politics of Resentment. New York: Macmillan Corporate.

[3] Holy Bible (1996, New International Version). 1 Corinthians (8:2). Hong Kong: Chinese Bible International Limited.

[4] Lee, Danjie. (2015). On Cross-Cultural Identity. Academy.No.10, Vol. 35, p.27-28.

[5] Li, Zongqiang. (2015). Literature Review of English Teaching and Identity in China. Journal of Harbin University, No. 7 , Vol.36, p.121-124.

[6] Ma, Wenli. (2013). Literature Review of an English Teacher's Identity at National Colleges. Journal of Yangtze University (Social Science Edition), No.11, Vol.36, p.151-152.

[7] Noonan, Harold W. (2003). Personal Identity. New York: Routledge of the Taylor \& Francis Group.p.24-43.

[8] Qi, Xiaobin. (1994). The Construction and Deconstruction of Language Myth. Journal of Xi'an International Studies University, No.1, Vol.10, p.72-77.

[9] Wei, Zheng \& Liang, Zhang. (2018). Myths of Identity_- The Rise and Fall of Contemporary Western Identity Politics. Exploration and Free Views, No.11, Vol. 28, p.68-75.

5.See the book Identity: The Demand for Dignity and the Politics of Resentment written by Francis Fukuyama. New York: Macmillan Corporate, 2018, page $9-10$. 
Wensheng Deng was born in Anhua County, Hunan Province of China in 1967. He received his M.A.in literature from Central South University of China in 2002, and he has further trained his academics at Harding University of the USA from 2007 until 2008. And now he is Associate Professor of Anglo-American Literature of the Dept. of Foreign Languages at Beijing Institute of Petrol-chemical Technology, China. His scholastic studies cover Comparative Literature, Translation Studies, Film Studies and Politics.

Mr. Deng is a member of Chinese Association of Foreign Language Teachers. And he has published more than 30 papers home and abroad. 